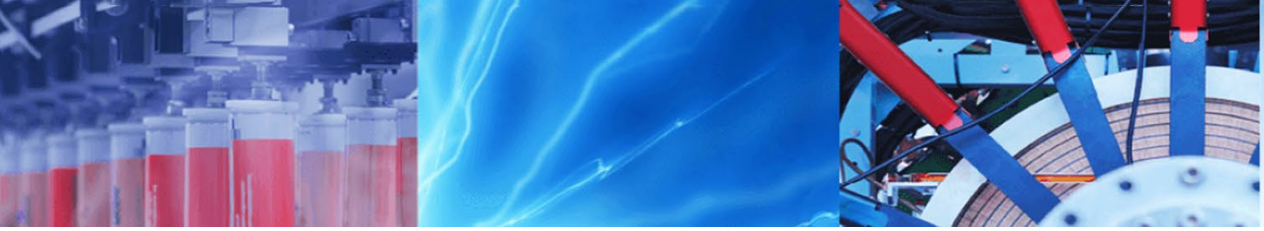

Research Article

\title{
Flexural behaviour of glass fibre reinforced polymer (GFRP) laminated hybrid-fibre reinforced concrete beams
}

\author{
B. Ramesh ${ }^{1}$ D $\cdot$ S. Eswari ${ }^{1} \cdot$ T. Sundararajan ${ }^{1}$
}

Received: 20 September 2019 / Accepted: 6 January 2020 / Published online: 13 January 2020

(c) Springer Nature Switzerland AG 2020

\begin{abstract}
The flexural behaviour of externally bonded glass fibre reinforced polymer (GFRP) reinforced concrete (RC) beams incorporating both 'basalt' and 'polyolefin' fibres at a constant ratio of 70:30 and in several combinations of fibre volume fractions $\left(\mathrm{V}_{\mathrm{f}}\right)$ ranging from $0-2 \%$ (at a constant increment of $0.5 \%$ ) were investigated, to highlight to role of strengthening and the hybrid fibres in beams. Three different types of beams, namely: a control beam (1 No.); GFRP laminated RC beam (1 No.) and laminated and hybrid fibre reinforced (HFRC) beams (4 Nos.) were cast, and tested under a four-point bending. The load-deflection response at: first crack, yield point, at initiation of debonding lamination and at ultimate stages were recorded by appropriate instrumentation. The results indicate that there is a 'combined effect' of lamination and incorporation of the above hybrid fibres in contributing to the very high load-carrying capacity and enhanced ductility of laminated HFRC beam, especially at a fibre volume content of $1.5 \%$. Further, the maximum yield and ultimate loadcarrying capacity of laminated HFRC beam is found to be $59 \%$ and $49 \%$ higher than the laminated RC beam and $125 \%$ and $98 \%$ higher than the control beam. However, the deflections are higher, and their permissibility have to be ascertained with respect to relevant codal provisions. All the laminated HFRC beams exhibited 'gradual debonding' and 'ductile' failure, whereas, the control beam exhibited 'flexural mode' of failure. The 'combined effect' can be used advantageously in structural applications, where both 'strength' and 'ductility' are important.
\end{abstract}

Keywords Flexural strength · GFRP · Basalt and Polyolefin fibres · Load-carrying capacity · Ductility · Modes of failure

\section{Introduction}

Reinforced concrete (RC) structures need upgrading for several reasons such as the effect of deterioration, mistakes in design and construction, changing in the use of structure, the excessive applied load resulting from increase in both traffic volume and truck weight, corrosion of internal steel reinforcement and freeze-thaw action. Several novel methods have been established in order to strengthen the RC structures, among the number of materials that have been adopted for external strengthening, Fibre Reinforced Polymer (FRP) materials have drawn considerable attention in recent decades, due to their proven advantages over steel plates [1]. External bonding using FRP laminates is most commonly used. There are many benefits of FRP like high strength to weight ratio, adaptable to curved surface, easy to handle, electrochemical corrosion resistant, available in any shape and length, resistance to fatigue, more ultimate strength and lesser density compared to steel, etc. are the few properties which make FRPs an ideal selection in terms of strengthening applications [2, 3]. Among the most common types of FRP, GFRP (glass fibre reinforced polymer) is easily available, apart from less costly than CFRP (carbon fibre reinforced polymer), and hence studies on strengthening using GFRP are more relevant, especially in countries like India.

B. Ramesh, bramesh0104@pec.edu; S. Eswari, eswaripec@pec.edu; T. Sundararajan, tsrajan_56@pec.edu|'Department of Civil Engineering, Pondicherry Engineering College, Pondicherry 605014, India. 
While strengthening enhances the load-carrying capacity, it has its own limitation/(s), such as, the ductility behaviour. The strengthening of beams using FRP laminates increase load carrying capacity and reduce the ductility of the beams. Galal and Amir [4] illustrated that the FRP strengthened beams have shown a load enhancement of $16 \%$ in the ultimate load when compared to that of control beam and deflection is $54 \%$ less than the control beam.

On the other hand, incorporation of fibres in cement/ cementitious matrix enhances the ductility of concrete [5-7]. Therefore, several types of fibres were incorporated into concrete, such as steel, glass, carbon, polypropylene, natural, fibres from pre-and post-consumer wastes, basalt and polyolefin fibres. Among all these fibres, steel fibres are stiffer and has high elastic modulus and thus incorporation of steel fibre into concrete effectively improves the compressive, flexural strength and impact resistance $[8,9]$. However, steel fibre poses several disadvantages, such as: easy rust formation, increased structural weight, fibre balling effect at high dosage, and thus reducing the workability [10]. For these reasons, the better alternative is glass fibre. Glass fibre has been used to produce light weight architectural elements. The drawback of glass fibre is high sensitivity in alkaline environment conditions. Carbon fibre has stiff and chemically inactive nature, but it has a disadvantage of high cost.

Extensive studies on the flexural behaviour of fibre reinforced concrete (FRC) beams were carried out, in the past several decades. The addition of waste metalized plastic (WMP) fibres along with palm oil fuel ash in concrete yielded great strength properties was studied Hosseini et al. [11], moreover, the incorporation of WMP fibres resulted in lower the drying shrinkage [12].

Basalt fibre is a new kind of inorganic fibre, made from basalt rocks, which are melted at $1400^{\circ} \mathrm{C}$, basalt fibres are environmentally safe, non-hazardous and non-toxic nature [13]. Basalt fibre is more economical in compare with glass and carbon fibres, because the raw materials required for basalt fibre are excessively available and the manufacturing process of basalt fibre include no additives [14]. Addition of basalt fibres can improve the energy absorption and deformation capacity, flexural strength, reduced the brittleness and improve the toughness index and reduce drying shrinkage of FRC significantly [15]. Resistance to high temperature [16]. Self-repairing of concrete cracks [17]. Dong et al. [18] studied the mechanical properties of concrete made with basalt fibre, the results showed that addition of basalt fibres enhanced concrete strength and ductility.

Recently macro synthetic fibres are being produced and promoted for use in structural applications. Specific advantages of these fibres over steel fibres include ease of handling, chemical inertness and enhance impact resistance.
Among synthetic fibres, Polyolefin fibre is one of the most popular reinforcing material in concrete.Polyolefin fibers are produced from organic polymers formed by the chain growth polymerization of olefins (alkenes) which contain greater than $85 \%$ polymerized propylene or ethylene [19]. Significant improvements in toughness and ductility with addition of polyolefin fibres in concrete [20]. Polyolefin fibres are less cost, when compared to steel fibre [21]. Bantia et al. [22] observed that, Polyolefin fibres acts to arrest the propagation of internal cracks, reduce the extent of shrinkage cracking, improve the ductility of concrete and less chance for segregation, balling and bleeding.

It is found from extensive literature review, that the studies on external strengthening of beams using FRP lamination. However, the combined effect of external strengthening and incorporation of fibres, more so, on the incorporation of hybrid fibres, comprising a combination of 'high' and 'low' modulus, is rather scarce [23]. On the other hand, such studies are needed, where the both 'strength' and 'ductility' are needed for certain structural applications. Hence, in this study, the flexural behaviour of RC beams laminated with GFRP and incorporating 'hybrid fibres' consisting of 'basalt' (high modulus) and 'polyolefin' (low modulus) have been experimentally investigated, and their 'combined effect' highlighted.

\section{Experimental program}

\subsection{Materials used}

Ordinary Portland cement (OPC) 53 grade conforming to IS: 12269-1987 [24]; locally available clean river sand passing through $4.75 \mathrm{~mm}$ sieve with a specific gravity of 2.63 and conforming to zone II as per IS: 383-2016 [25] as fine aggregate; crushed granite stone with specific gravity 2.75 having a maximum aggregate size of $20 \mathrm{~mm}$ as coarse aggregate, are the various materials used in concrete. Portable water was used for mixing and curing concrete. $10 \mathrm{~mm}$ and $8 \mathrm{~mm}$ diameter high yield strength deformed (HYSD) bars were used as main and secondary reinforcement in beams. The average ultimate tensile strength of the above bars are: $620 \mathrm{MPa}$ and $601 \mathrm{MPa}$ respectively, as determined by standard IS code.

Commercially available GFRP laminates of $5 \mathrm{~mm}$ thick were used as external reinforcement for strengthening of beams at the soffit. The above laminates are unidirectional. Salient properties of the laminate, as furnished by the manufacture are listed in Table 1. Commercially available two types of fibres, namely: basalt (high modulus) and polyolefin (low modulus) were selected for the present study. The above fibres taken together will form the 'hybrid fibres' in this study and will be referred to as such, 
Table 1 Properties of tensile steel bar and GFRP laminates

\begin{tabular}{lllllll}
\hline SI. No & Properties & $\begin{array}{l}\text { Tensile } \\
\text { steel ratio }\end{array}$ & No. of layers & $\begin{array}{l}\text { Ultimate } \\
\text { stress (MPa) }\end{array}$ & $\begin{array}{l}\text { Modulus of } \\
\text { elasticity (MPa) }\end{array}$ & Poisson's ratio \\
\hline 1 & Tensile steel & 1.04 & - & 620 & $2 \times 10^{5}$ & 0.3 \\
2 & GFRP laminates & - & 3 & 503.2 & 1603.5 & 0.38 \\
\hline
\end{tabular}

Table 2 Properties of basalt and polyolefin fibre

\begin{tabular}{llll}
\hline SI. No. & Fibre Properties & Fibre details \\
\cline { 3 - 4 } & & Basalt & Polyolefin \\
\hline 1 & Length $(\mathrm{mm})$ & 18 & 48 \\
2 & Size $(\mathrm{mm})$ or dia & 1 & 1.22 \\
3 & Aspect ratio & 18 & 39.34 \\
4 & Density $\left(\mathrm{Kg} / \mathrm{m}^{3}\right)$ & 2750 & 920 \\
5 & Specific gravity & 2.75 & 0.92 \\
6 & Young's modulus (GPa) & $79.3-93.1$ & $6.0-6.1$ \\
7 & Tensile strength (MPa) & $3000-4840$ & 550 \\
\hline
\end{tabular}

Table 3 Details of mix proportion

\begin{tabular}{lll}
\hline SI. No. & Material & Quantity \\
\hline 1 & Cement $\left(\mathrm{Kg} / \mathrm{m}^{3}\right)$ & 387 \\
2 & Fine aggregates $\left(\mathrm{Kg} / \mathrm{m}^{3}\right)$ & 761 \\
3 & Coarse aggregate $\left(\mathrm{Kg} / \mathrm{m}^{3}\right)$ & 1096 \\
4 & Water $\left(\mathrm{Kg} / \mathrm{m}^{3}\right)$ & 186 \\
5 & Water $/$ cement ratio & 0.48 \\
\hline
\end{tabular}

throughout the present study. Salient properties of the fibres, as provided by the manufacture are given in Table 2 .

\subsection{Mix proportioning and preparation of specimens}

IS: 10262 [26] method of mix design was adopted to produce a workable concrete, with a target mean strength of 31.6 MPa using the above materials, which formed the 'control concrete'. The details of the mix proportioning are given in Table 3. Basalt and polyolefin fibres were mixed in the ratio of 70:30 and incorporated into 'control beam' for casting hybrid fibre reinforced concrete (HFRC) beam specimens. The above ratio is maintained constant throughout the study. The fibre volume fraction $\left(V_{f}\right)$ was varied from 0 to $2 \%$, with an interval of $0.5 \%$ and incorporated for casting HFRC beam specimens. The ratio of hybrid fibres and range of $\mathrm{V}_{\mathrm{f}}$ used in this study are based on literature and/ or the earlier investigations of the author/(s) in the area of fibre reinforced concrete.

Rectangular beam of size $100 \mathrm{~mm} \times 150 \mathrm{~mm} \times 1000 \mathrm{~mm}$ (width $\mathrm{x}$ depth $\mathrm{x}$ length) with a longitudinal reinforcement ratio of $1.04 \%$ (10 $\mathrm{mm}$ dia.) and 2 legged $8 \mathrm{~mm}$ dia. as stirrups at $100 \mathrm{c} / \mathrm{c}$ as shear reinforcement, were cast using 'control concrete'. It is referred as the 'control beam'. Figure 1 shows the details of 'control beam'. The control beam was designed as per IS: 456-2000 [27]. The control beam was strengthened using GFRP laminates adopting the 'wet layup system' and in accordance with $\mathrm{ACl}$ guidelines, $\mathrm{ACl}$ $440.2 \mathrm{R}-2008$ [2]. Such beams were referred to as 'laminated $\mathrm{RC}$ beam/(s)', in this study. Before bonding the laminate, the surface of beams, namely, the tension side, as well as edges and corners of beams were grinded smoothly using mechanical grinder with a stone wheel, and the debris, loose materials etc., were cleared using an air blower. The prepared surface is coated with a primer and after curing period, epoxy (the adhesive) resin mixed with hardener (as suggested by the manufacture) in the ratio 4:1 was applied uniformly over the surface and on to the GFRP sheets using a brush. Prior to applying the adhesive, GFRP sheets were cut to the required size $(100 \mathrm{~mm} \times 1000 \mathrm{~mm})$ to form the GFRP laminate for strengthening the beam. The prepared GFRP sheets were placed on the prepared concrete surface and gently pressed using a rubber roller to expel air voids that might have entrapped between the concrete surface and GFRP laminate. The beams are then cured at room temperature, before testing. The various stages of casting the laminated beam are shown in Figs. 2 and 3. In all, one 'control beam' one 'laminated RC beam' and four 'laminated HFRC beams', were cast. The designation of the above beams are summarized in Table 4.

\subsection{Test set-up and testing}

Before commencement of testing, all the beams were wiped, white washed and dried. Then grid lines were drawn (block colour) at $50 \mathrm{~mm}$ intervals, to enable mapping of cracks during testing. A universal testing machine of capacity $1000 \mathrm{kN}$ (available in the Civil Engineering Department) was used for testing the beams in flexure, under a four point bending, and in accordance with IS: 516-1959 [28]. The beam were simply supported, with an effective span of $900 \mathrm{~mm}$, and a bearing of $50 \mathrm{~mm}$ on either ends. A steel I section was used as a spreader beam and load was applied through load cells. A constant rate of loading of $2.5 \mathrm{kN}$ was maintained during testing. The distance between the contact points of load transfer on the beam was $300 \mathrm{~mm}$. The deflections at mid span were measured using a standard mechanical 


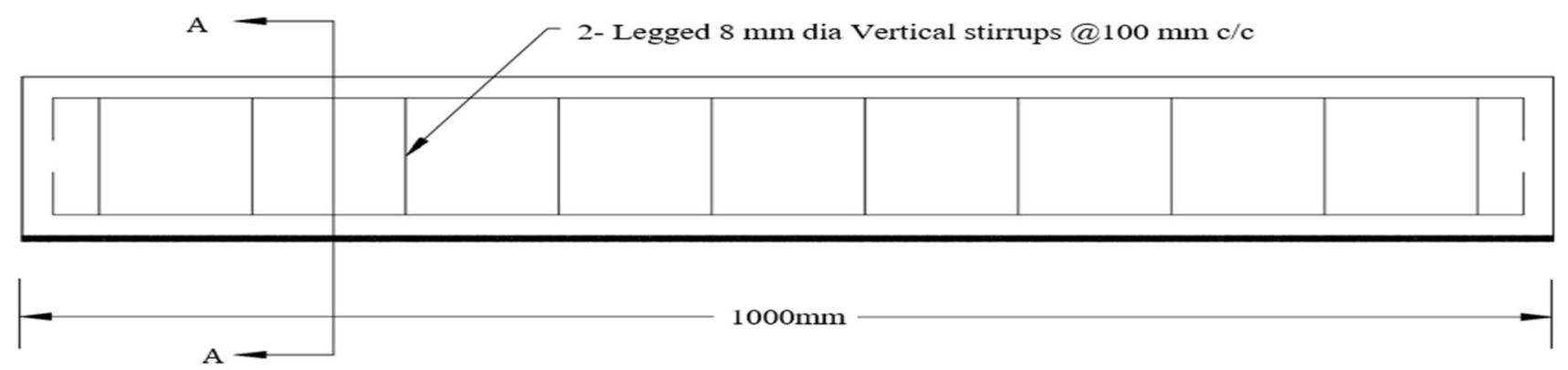

(a)

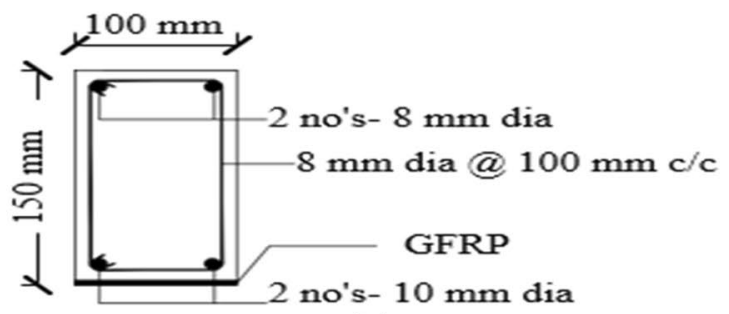

(b)

Fig. 1 Reinforcement details of beam: a Longitudinal section; b Cross-section at A-A

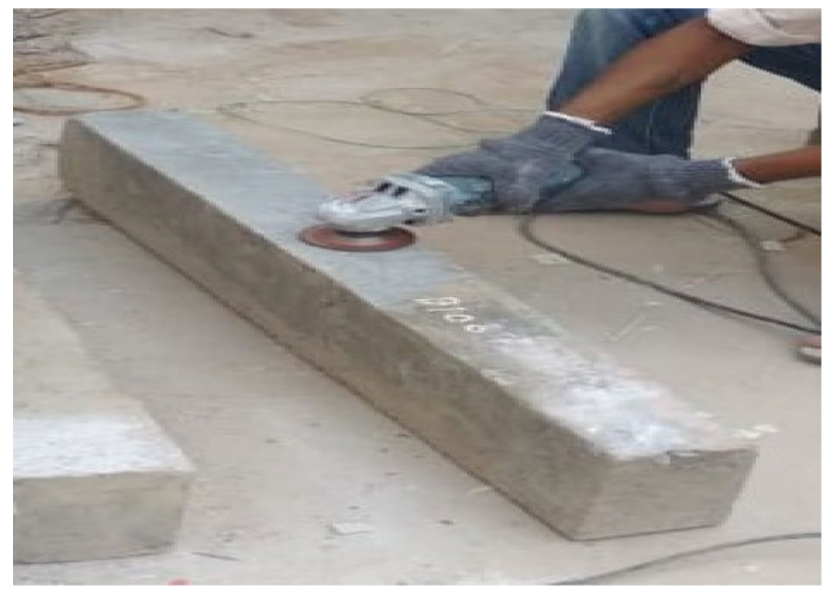

Fig. 2 Surface grinding in progress

dial gauge having an accuracy of $0.01 \mathrm{~mm}$. The beams were loaded until failure. Salient experimental data like the load (in kN), deflections (in $\mathrm{mm}$ ) were continuously recorded at each load interval, and at first crack, yield point, debonding of laminate and ultimate stage. The above data was then used for computing the strength and ductility of all tested beams. Further, crack propagation and distribution were observed and marked on all tested beams during testing. The above data and observations were then used for critical analysis to obtain salient results and conclusions from this study. A schematic view of the experimental set-up is shown in Fig. 4.

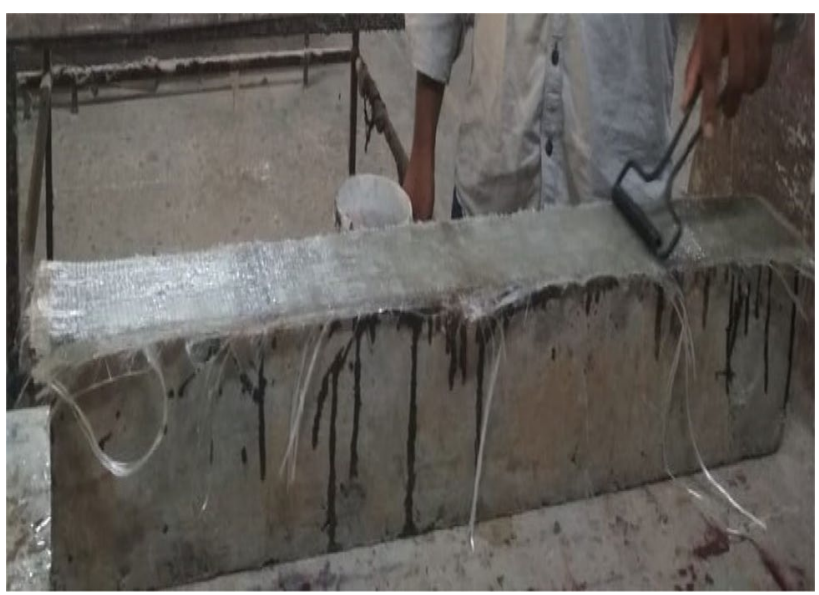

Fig. 3 Removing of air voids using roller

\section{Results and discussion}

\subsection{Load-carrying capacity}

Principle test results of beams are summarized in Table 5 and comparison of loads of all the tested beams are shown in Fig. 5. It can be inferred from the results that the loadcarrying capacity of laminated RC beam (HBOL5), at firstcrack, yield and ultimate stages have increased by about $31 \%, 41 \%$ and $33 \%$ respectively, when compared to the control beam. This shows the influence of GFRP lamination on the load carrying capacity of the strengthened

\section{SN Applied Sciences}


Table 4 Specimen details

\begin{tabular}{llllll}
\hline SI. No. & Beam designation & $\begin{array}{l}\text { Fibre volume } \\
\text { fraction (\%) }\end{array}$ & \multicolumn{2}{l}{ Proportion of fibres } & $\begin{array}{l}\text { GFRP laminate } \\
\text { thickness (mm) }\end{array}$ \\
\cline { 3 - 5 } & & Basalt & Polyolefin n & \\
\hline 1 & HB 0 L0 & 0.0 & - & - & - \\
3 & HB 0 L5 & 0.0 & - & - & 5 \\
4 & HB0.5 L5 & 0.5 & 70 & 30 & 5 \\
5 & HB1.0 L5 & 1.0 & 70 & 30 & 5 \\
6 & HB1.5 L5 & 1.5 & 70 & 30 & 5 \\
\hline
\end{tabular}

${ }^{\mathrm{a} H B O L O-c o n t r o l ~ b e a m ~}$

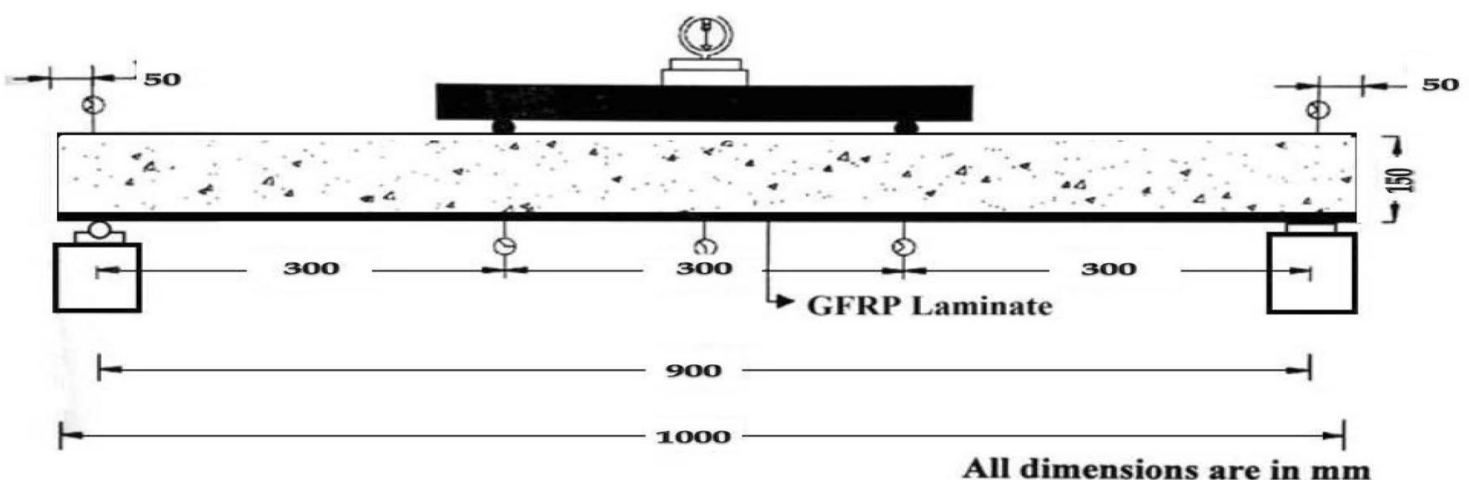

Fig. 4 Schematic diagram of experimental test setup

Table 5 Results of tested beams

\begin{tabular}{|c|c|c|c|c|c|c|c|c|c|}
\hline SI. No & $\begin{array}{l}\text { Beam desig- } \\
\text { nation }\end{array}$ & $\begin{array}{l}\text { First crack } \\
\text { load (kN) }\end{array}$ & $\begin{array}{l}\text { First crack } \\
\text { deflection } \\
(\mathrm{mm})\end{array}$ & $\begin{array}{l}\text { Yield load } \\
(\mathrm{kN})\end{array}$ & $\begin{array}{l}\text { Yield load } \\
\text { Deflection } \\
(\mathrm{mm})\end{array}$ & $\begin{array}{l}\text { Load at } \\
\text { debonding } \\
\text { initiation (kN) }\end{array}$ & $\begin{array}{l}\text { Deflection } \\
\text { at debond- } \\
\text { ing initiation } \\
(\mathrm{mm})\end{array}$ & $\begin{array}{l}\text { Ultimate } \\
\text { load (kN) }\end{array}$ & $\begin{array}{l}\text { Ultimate load } \\
\text { deflection } \\
(\mathrm{mm})\end{array}$ \\
\hline 1 & HB O LO & 17.54 & 1.25 & 34.00 & 3.61 & - & - & 42.34 & 8.60 \\
\hline 2 & HB 0 L5 & 23.00 & 1.30 & 48.00 & 3.76 & 51.29 & 4.24 & 56.5 & 6.30 \\
\hline 3 & HB0.5L5 & 28.16 & 1.90 & 57.82 & 4.05 & 62.43 & 5.16 & 68.5 & 10.6 \\
\hline 4 & HB1.0L5 & 31.42 & 2.45 & 71.00 & 5.00 & 73.38 & 5.84 & 77.5 & 12.6 \\
\hline 5 & HB1.5L5 & 35.32 & 2.73 & 76.50 & 5.50 & 79.42 & 6.83 & 84.00 & 15.00 \\
\hline 6 & HB2.0L5 & 33.14 & 2.61 & 71.50 & 5.32 & 73.61 & 6.00 & 80.00 & 13.52 \\
\hline
\end{tabular}

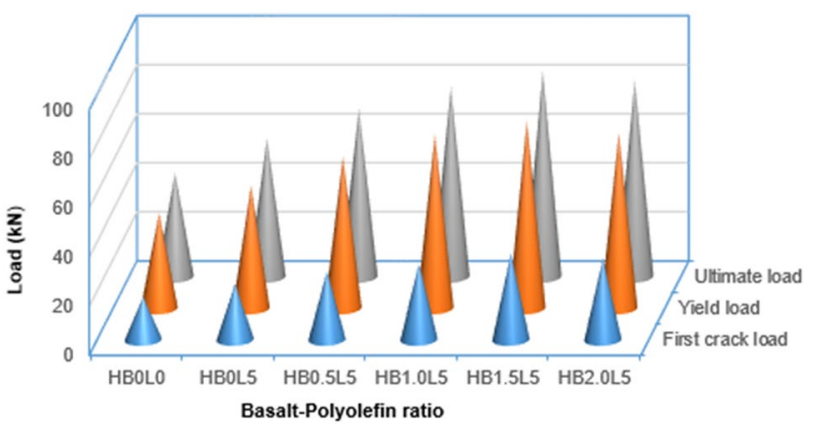

Fig. 5 Load comparison at various stages of tested beams beam, which is along expected lines. It should be noted that the increase in the load is highest, among the above three stages, at yield point. However, the above (highest) level of increase could not be sustained beyond the yield point, may be due to sudden debonding of the laminate. Nonetheless, the very high increase in the load carrying capacity due to GFRP lamination can be advantageously used in actual structural engineering applications. Numerous investigations by researchers such as Aravind et al. [29], Nayak et al. [30], have reported that the use of GFRP laminates for strengthening of RC beams increases the ultimate load-carrying capacity significantly. 


\subsection{Effect of addition of hybrid (basalt and polyolefin) fibres}

As proportion of hybrid fibres was maintained constant throughout the study, only the variation of actual fibre volume content $\left(\mathrm{V}_{\mathrm{f}}\right)$ will have an effect on the load carrying capacity and other characteristics of the HFRC beams. As the $V_{f}$ increases from $0.5 \%$ to $1.5 \%$, the first crack load, yield load and ultimate load of 'laminated and hybrid fibre-reinforced beams' (HB0.5L5 to HB1.5L5) gradually increases, and reaches the maximum, when the $V_{f}=1.5 \%$ (Fig. 5). However, at the maximum $V_{f}$ used $\left(V_{f}=2.0 \%\right)$, the load carrying capacity attained by the beam, at all the three stages are lower than the $V_{f}=1.5 \%$. This shows the desured hybrid volume content is $1.5 \%$, to achieve the maximum load-carrying capacity of HFRC beam (among the range of $\mathrm{V}_{\mathrm{f}}$ considered). The maximum load carrying capacity of 'laminated HFRC beam' (HB1.5L5) at first-crack, yield and ultimate stages are respectively, about 54\%, 59\% and $49 \%$ higher than the 'laminated RC beam' (HBOL5) and about 101\%, 125\%, 98\% higher than then 'control beam' (HBOL0) (Table 5). This shows that the hybrid fibres used in this study have contributed to'very high' increase in the load carrying capacity of laminated HFRC beam (HB1.5L5).

Comparing the load-carrying behavior of 'control beam', 'laminated RC beam' and 'laminated HFRC beam', following inferences are drawn: (i) Lamination contributes to the increase in the load carrying capacity at all three stages; namely: at first crack,yield and ultimate. However, its contribution to the post-yield stage is less than at yield point, which may be attributed to the 'debonding' of lamination at or beyond yield point; (ii) Inclusion of hybrid fibres contribute to very high increase in the load-carrying at all three stages of 'laminated beam' and its post-crack behaviour due to 'arresting or bridging' the micro-cracking development due to loading, there- by, increasing the interfacial bond in concrete matrix and increasing the ductility of the beam; (iii) There is a 'combined effect' of lamination and 'inclusion of hybrid fibres contributing to the very high load-carrying capacity and enhanced ductility of 'laminated HFRC beams' which is highly advantageous and can be used for structural applications where the twin objectives of higher load- carrying capacity and post-yield behaviour are to be fulfilled. Lijuan et al. [31] Yin and Wu [32] have also found the same observations on the improvement in the load carrying capacity of GFRP laminated beams by incorporating of steel and polypropylene fibres.

\subsection{Deflection behaviour}

Deflection of the laminated RC beam at ultimate stage is lower than the 'control beam'. Deflection of laminated
HFRC beams increase with the increase in $V_{f}$ content up to $1.5 \%$ and after there decrease at $V_{f}=2.0 \%$. The above two behaviour are similar to the behaviour of load-carrying capacity, from the stage of first-crack formation to the ultimate stage. But, the only difference is in the actual value of deflection at the three stages, especially, the post-yield stage. Deflection is maximum for the laminated HFRC beam, when $V_{f}=1.5 \%$ (HB1.5L5), at all the three stages (Table 5) and that the above maximum deflection $(2.73 \mathrm{~mm} ; 5.50 \mathrm{~mm}$ and $15.00 \mathrm{~mm}$, respectively) is $118.4 \%, 52.8 \%$ and $74.4 \%$ higher than the 'control beam' at corresponding stages. Similarly, the maximum deflection of the above is $110 \%, 46.8 \%$ and $138.1 \%$ higher than the 'laminated beam'. Comparing the above two sets of increase in deflection of respective beam/(s) over control beam reveal: (i) In general, the increase in deflection may be attributed to the increase in the load-carrying capacity of beam due to lamination and/or hybrid-fibre reinforcement. (ii) However, lamination of beam makes the beam stiffer, and that the role of fibres comes into play only after initiation of first crack and thus, contributing to the ductility. (iii) From an actual structural application point of view the maximum deflection exhibited by the 'laminated HFRC beam' is desirable or permissible, has to be ascertained with respect to the 'relevant codal provision/(s)'. The findings of the current study are firmly comparable to that reported by Syeed et al. [33] for SFRC beams strengthened with GFRP laminates.

\subsection{Load-deflection response}

The load-deflection behaviour of all tested beams are presented in Fig. 6. Linear-elastic behaviour is better exhibited by all beams, excepting the 'control beam' and the linear-elastic behaviour is at its best for laminated HFRC beams, especially, when the $V_{f}$ is greater than $0.5 \%$ (Fig. 6). On overall assessment of the load-deflection response, 'laminated HFRC beams' exhibit better pre and post yield behaviour, than the other two type of beams, considered in this study.

\subsection{Ductility}

Ductility is the capacity of a beam to undergo large deformation, with marginal increase in load. 'Deflection ductility' is defined as the 'ratio of mid-span deflection at ultimate load to the yield load.' 'Ductility ratio' is defined as the 'ratio of ductility of a beam to that of a control beam'. The values of ductility and ductility ratios of tested beams are summarized in Table 6 and the comparisons are shown in Fig. 7. The ductility of all laminated HFRC beams increase with increase in $V_{f}$ up to $1.5 \%$ and there after decrease when $V_{f}$ is $2.0 \%$. The above behaviour is similar to that of 
Fig. 6 Load deflection response of tested beams
Table 6 Ductility and failure mode of tested beams

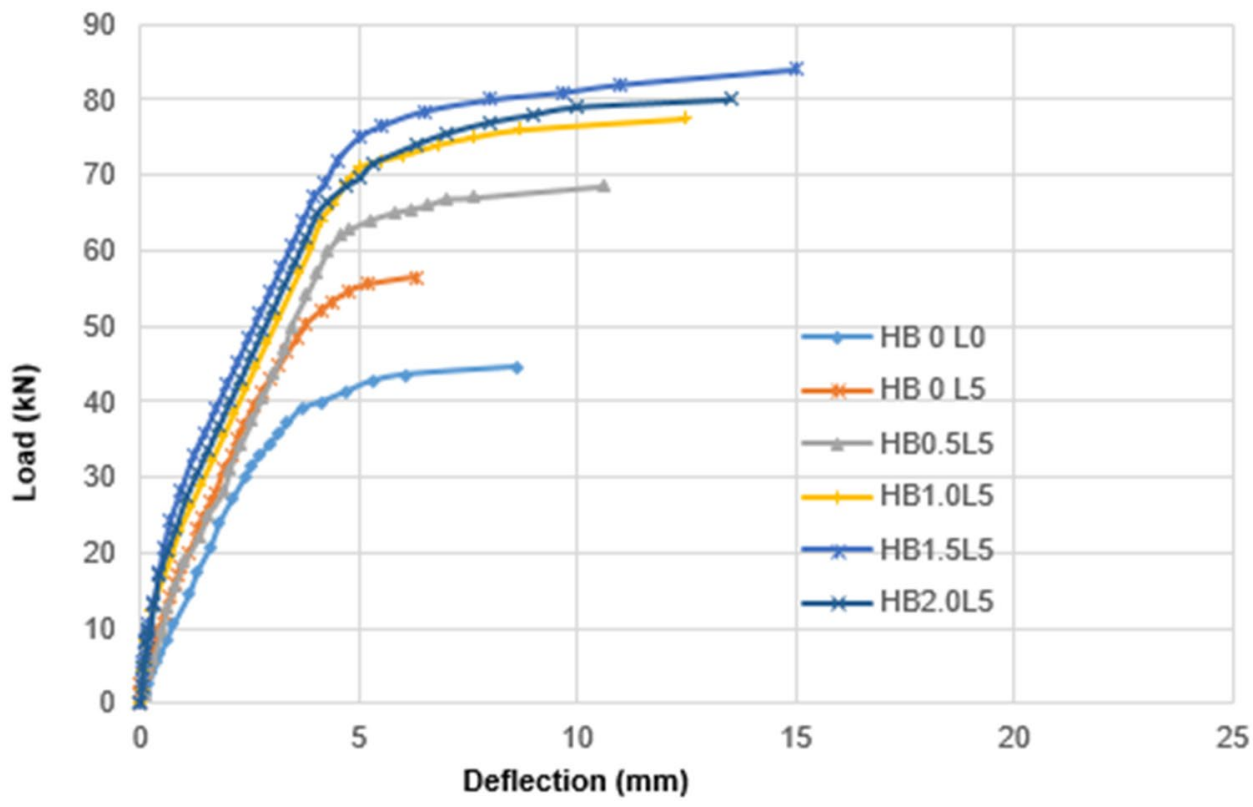

\begin{tabular}{lllll}
\hline SI.No. & Beam designation & Ductility & Ductility ratio & Mode of failure \\
\hline 1 & HB O L0 & 2.38 & 1 & Flexural failure \\
2 & HB 0 L5 & 1.67 & 0.70 & Sudden debondig of GFRP laminates \\
3 & HB0.5L5 & 2.30 & 0.96 & Gradual debonding of GFRP laminates \\
4 & HB1.0L5 & 2.51 & 1.05 & Gradual debonding of GFRP laminates \\
5 & HB1.5L5 & 2.72 & 1.62 & Gradual debonding of GFRP laminates \\
6 & HB2.0L5 & 2.56 & 1.07 & Gradual debonding of GFRP laminates \\
\hline
\end{tabular}

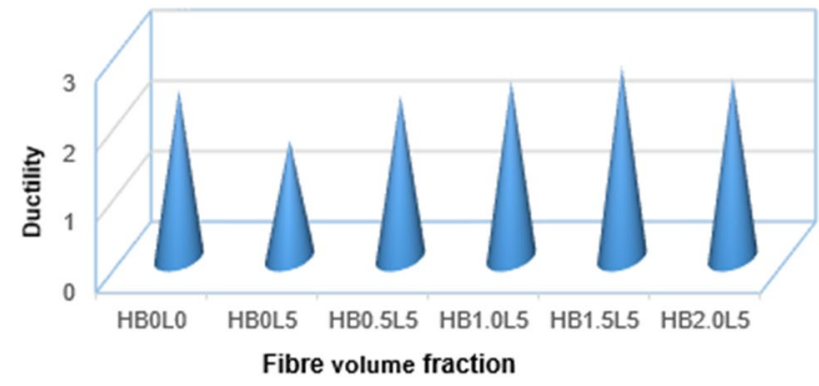

Fig. 7 Ductility of tested beams

load-carrying capacity and deflection of the above beam. However, mere lamination of beam (HBOL5) has reduced the ductility by about $30 \%$ than the 'control beam (HBOLO)', which is clearly due to the 'stoppening effect' of lamination, on the tension face of the beam, even though the actual material used for lamination is a lightweight and flexible material. Similar behaviour (as stated above) has been reported by Spadea et al. [34] and Hawish et al. [35] due to CFRP and GFRP lamination on tension face of a beam. Thus, there will be stiffening effect of lamination, irrespective of the type of lamination, whereas, the 'degree of stiffening' may vary. This 'stiffening effect' contributes to the increased load-carrying capacity up to the 'debonding' of laminate. Ductility and ductility ratios are maximum for the strengthened HFRC beam with $V_{f}=1.5 \%$, which incidentally also carries the maximum load. Thus, there is combined effect of lamination and hybrid-fibre reinforcement, which is highly advantageous for structural applications. It is to be noted that the increase in ductility of laminated HFRC beam (HB1.5L5) is $62 \%$ than the mere laminated $\mathrm{RC}$ beam, which is very very high, and may be attributed slowly to the addition of this kind of hybrid-fibres used in this study.

\subsection{Debonding behaviour and failure modes}

Load at initiation of debonding of laminate and the corresponding deflection at that stage for all beams tested are summarized in Table 5 . The load at initiation of debonding and the corresponding deflection for all strengthened HFRC beams (HB0.5L5 to HB1.5L5) increase with the increase in $V_{f}$ up to $V_{f}=1.5 \%$ and thereafter decrease for $V_{f}=2.0 \%$ (HB2.0L5). The above trend is similar to the 


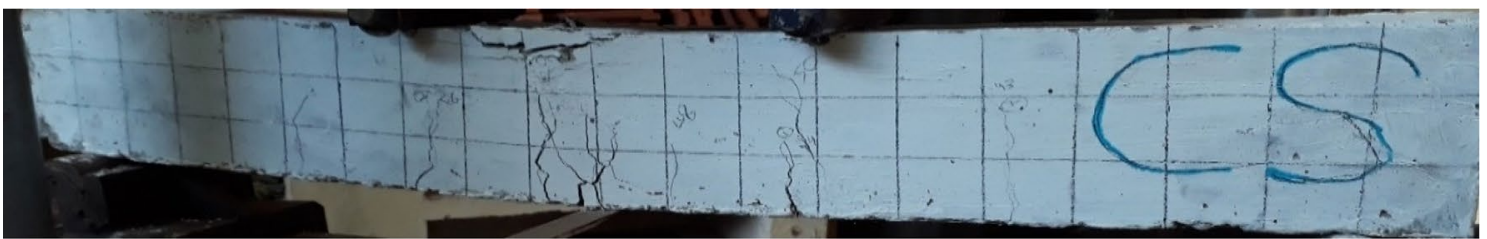

(a) Control beam (HBOL0)

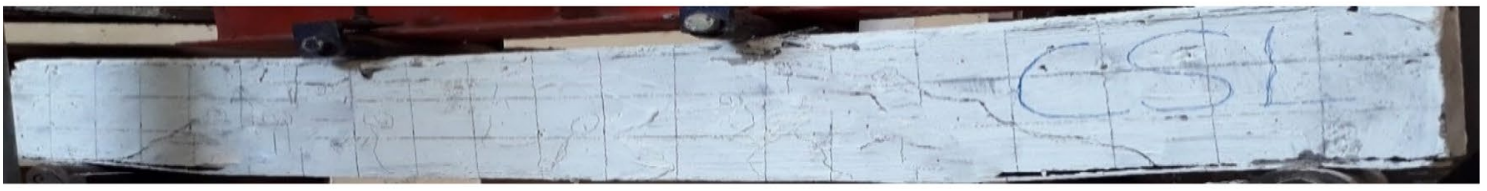

(b) Laminated RC beam (HB0L5)

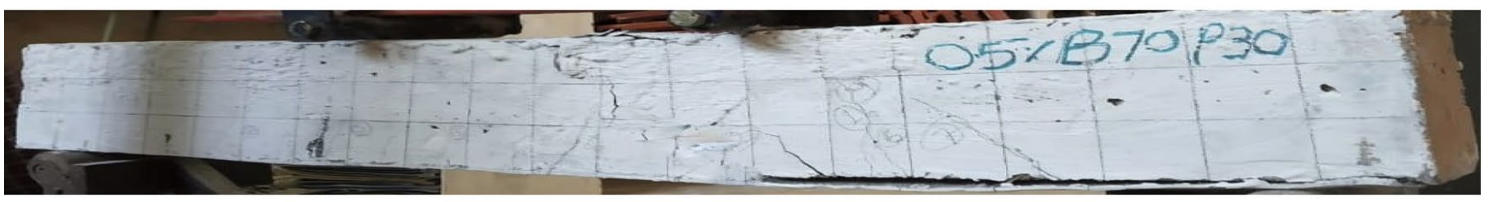

(c) Laminated HFRC beam (HB0.5L5)

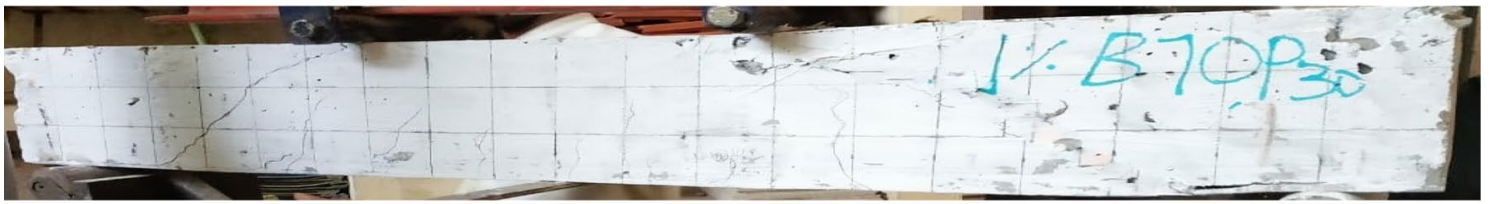

(d) Laminated HFRC beam (HB1.0L5)

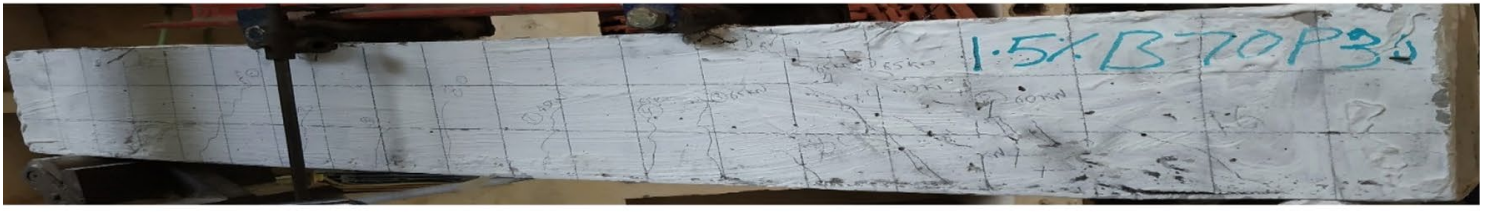

(e) Laminated HFRC beam (HB1.5L5)

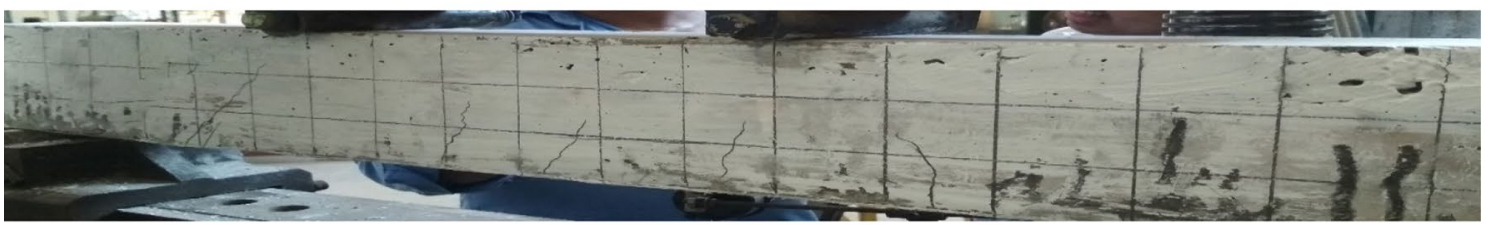

(f) Laminated HFRC beam (HB2.0L5)

Fig. 8 a-f Failure modes of all tested beams

behaviour of load-carrying capacity and deflection at first crack, yield point and at ultimate stage of the above beams. However, the actual load at initiation of debonding and deflection at debonding lies between the yield point and ultimate stage, more specifically, slightly higher than the value of yield point. In other words, debonding (sudden/gradual) of the laminate occur immediately after the yield point for laminated and/or laminated HFRC beams.
Any further increase in the load carrying capacity of the above beams is primarily due to the incorporation of hybrid fibres. On the other hand, the deflection of laminated HFRC beams at ultimate stage increases by more than two times than at the stage of initiation of debonding. This shows the ductility effect of hybrid fibres used and plays a very significant role, especially, after'debonding of

\section{SN Applied Sciences}


laminate'. The above phenomenon correlates well with the actual values of ductility/ductility ratios (Table 6).

The failure modes of all tested beams are shown in Fig. 8a-f. As expected, the 'control beam' exhibits'flexural mode' of failure, whereas laminated HFRC beams exhibit gradual debonding of laminate and ductile failure. The RC beam with lamination only exhibit sudden debonding of laminate. Further, thin and short vertical cracks appear at mid-span in tension zone in the laminated $\mathrm{RC}$ beam. However, in laminated HFRC beams more number of fine and uniform cracks appear closely, when compared to laminated RC beam.

\section{Conclusions}

(i) GFRP lamination has contributed to the increase in the load-carrying capacity at first crack, yield and ultimate stages of a RC beam than the 'control beam' (that is un-laminated RC beam).

(ii) There is a combined effect of lamination and inclusion of hybrid fibres, in contributing to the very high load-carrying capacity and enhanced ductility of laminated HFRC beam, especially, a fibre volume content of $1.5 \%$, with the ratio of 70:30 (basalt: polyolefin). The above unique advantages can be used for structural applications, where, both loadcarrying capacity and ductility are required.

(iii) The maximum yield and ultimate load- carrying capacity of laminated HFRC beam with $\mathrm{V}_{f}=1.5 \%$ and $5 \mathrm{~mm}$ thick GFRP lamination (HB1.5L5), is $59 \%$ and $49 \%$ higher than laminated RC beam (HBOL5) and $125 \%$ and $98 \%$ higher than the control beam (HBOLO).

(iv) However, the deflection of the above beam $5.5 \mathrm{~mm}$ and $15.0 \mathrm{~mm}$ respectively at yield and ultimate stages and the above maximum deflections are $46.8 \%$ and $138.1 \%$ higher than the laminated RC beam. The permissibility of the above deflection values have to be ascertained with respect to relevant codal provisions for a particular structural application.

(v) Laminated HFRC beam (HB1.5L5) has the highest ductility and is $62 \%$ higher than laminated RC beam (HBOL5), which is very highly advantageous from an application point of view.

(vi) All the laminated beams have failed by 'debonding' just after the 'yield point' and ductile failure thereafter, until ultimate stage.

Acknowledgments The authors of this paper acknowledge the financial support provided by University Grant Commission (UGC), File no:
MRP-6466/16(SERC/UGC), New Delhi, for carrying out this research work successfully. The authors also thank the Elasto-Plastic Concrete (Europe) Ltd for their support in providing polyolefin fibres to carry out the research work. The authors are also thankful to Pondicherry Engineering College for providing laboratory facilities for testing.

\section{Compliance with ethical standards}

Conflict of interest The author(s) declares that they have no conflict of interest.

\section{References}

1. Qeshta IMI, Shafigh P, Jumaat MZ (2016) Research progress on the flexural behaviour of externally bonded RC beams. Arch Civil Mech Eng 16:982-1003. https://doi.org/10.1016/j. acme.2016.07.002

2. American Concrete Institute (ACI) (2008). Guides for the design and construction of externally bonded frp system for strengthening concrete structures. $\mathrm{ACl} 440.2 \mathrm{R}-08$, Farmington Hills, MI

3. JSCE (2001) Recommendations for upgrading of concrete structures with use of continuous fibre sheets, vol 41. Japan concrete engineering series. Japan Society of Civil Engineers, Tokyo

4. Galall K, Amir M (2009) Strengthening RC beams in flexure using new hybrid FRP sheet/ductile anchor system. J. Compos Constr 13(3):217-225. https://doi.org/10.1061/ASCECC.1943-5614.0000006

5. Abdul Awal ASM, Mohammadhosseini H (2016) Green concrete production incorporating waste carpet fiber and palm oil fuel ash. J Clean Prod 137:157-166. https://doi.org/10.1016/j.jclep ro.2016.06.162

6. Mohammadhosseini H, Tahir MM, Sam ARM (2018) The feasibility of improving impact resistance and strength properties of sustainable concrete composites by adding waste metalized plastic fibres. Constr Build Mater 169:223-236. https://doi. org/10.1016/j.conbuildmat.2018.02.210

7. Eswari S (2017) Ductility response of hybrid fibre reinforced concrete beams. J Urban Environ Eng 11(2):174-179. https:// doi.org/10.4090/juee.2017.v11n2.174179

8. ACl Committee 544 (1989) Measurement of properties of fibre reinforced concrete, $\mathrm{ACl}$ 544.2R-889, American Concrete Institute, Detroit, Michigan, USA

9. CNR-DT204/2006 (2007), Guide for the design and construction of fiber-reinforced concrete structures, National Research Council, Rome

10. Antoni N (1999) Fatigue behavior of steel fibre reinforced concrete. Cem Concr Compos 13(4):717-723

11. Mohammadhosseini $\mathrm{H}$, Tahir MM, Alyousef $\mathrm{R}$, Alabduljabbar $\mathrm{H}$, Mustafa S (2019) Effect of elevated temparatures on properties of sustainable concrete composites incorporating waste metalized plastic fibres. SN Appl Sci 1:1344. https://doi.org/10.1007/ s42452-019-1587-9

12. Mohammadhosseini $H$, Tahir MM (2018) Durability performance of concrete incorporating waste metalized plastic fibres and palm oil fuel ash. Constr Build Mater 180:92-102. https://doi.org/10.1016/j.conbuildmat.2018.05.282

13. Borhan TM (2012) Properties of glass concrete reinforced with short basalt fibre. Mater Des 42:265-271. https://doi. org/10.1016/j.matdes.2012.05.062

14. Lopresto V, Leone C, lorio I (2011) Mechanical characterization of basalt fibre reinforced plastic. Compos B Eng 42(4):717-723. https://doi.org/10.1016/j.compositesb.2011.01.030 
15. Li Weimin, Jinyu Xu (2009) Mechanical properties of basalt fibre reinforced geopolymeric concrete under impact loading. Mater sci Eng 505:178-186. https://doi.org/10.1016/j. msea.2008.11.063

16. Fiore V, Bella G, Valenza A (2011) Glass-basalt hybrid composites for marine applications. Mater Des 32:2091-2099. https://doi. org/10.1016/j.matdes.2010.11.043

17. Vijay K, Meena M (2019) Self-repairing of concrete cracks by using bacteria and basalt fibre. SN Appl Sci 1:1344. https://doi. org/10.1007/s42452-019-1404-5

18. Dong JF, Wang QY, Guan ZW (2017) Material properties of basalt fibre reinforced concrete made with recycled earthquake waste. Constr Build Mater 130:241-251. https://doi.org/10.1016/j. conbuildmat.2016.08.118

19. Yin S, Tuladhar R, Shanks RA, Jocob M (2015) Fibre preparation and mechanical properties of recycled polypropylene for reinforcing concrete. J Appl Polymer Sci 132(16):41866. https://doi. org/10.1002/app.41866

20. Alberti MG, Enfedaque A, Galvez JC (2014) On the mechanical properties and fracture behavior of polyolefin fiber-reinforced self-compacting concrete. Constr Build Mater 55:274-288. https ://doi.org/10.1016/j.conbuildmat.2014.01.024

21. Jerrett $D$, Cuddington $T$ (2008) Broadening the statistical search for metal price super cycles to steel and related metals. Resour Policy 33:188-195. https://doi.org/10.1016/j.resou rpol.2008.08.001

22. Banthia N, Yan C (2000) Shrinkage cracking in polyolefin fiberreinforced concrete. ACI Mater J 97(4):432-437

23. Ibrahim SS, Eswari S, Sundararajan T (2018) Behaviour of hybrid fibre reinforced concrete beams strengthened with GFRP laminates. Struct Eng Mech 66(5):631-636. https://doi.org/10.12989 /sem.2018.66.5.631

24. IS 12269 (2013) Ordinary portland cement, 53 grade specification,New Delhi, India: Bureau of Indian Standards

25. IS 383 (2016) Specification for fine and coarse aggregates from natural sources for concrete, Bureau of Indian Standards, New Delhi

26. IS 10262 (2009) Indian standard recommended guidelines for concrete mix design, New Delhi: Bureau of Indian Standards
27. IS 456-2000: Code of practice for plain and reinforced concrete, New Delhi: Bureau of Indian Standards

28. IS: 516-1959: Indian standard code for methods of tests for strength of concrete, Bureau of India, New Delhi

29. Aravind N, Samanta K, Joseph V, Singha Roy DK (2019) Comparative study on the performance of corrugated GFRP laminates on normal and pre-cracked flexural concrete members. Asian J Civ Eng 20:799-806. https://doi.org/10.1007/s42107-019-00145-x

30. Nayak AN, Kumari A, Swain RB (2018) Strengthening of RC beams using externally bonded fibre reinforced polymer composites. Struct. https://doi.org/10.1016/j.istruc.2018.03.004

31. Li Lijuan, Yongchang G, Liu F (2008) Test analysis for FRC beams strengthened with externally bonded FRP sheets. Constr Build Mater 22:315-323. https://doi.org/10.1016/j.conbuildma t.2006.08.016

32. Yin J, Wu ZS (2003) Structural performances of short steel-fiber reinforced concrete beams with externally bonded FRP sheets. Constr Build Mater 17:463-470. https://doi.org/10.1016/S0950 -0618(03)00044-8

33. Syed Ibrahim S, Eswari S, Sundararajan T (2016) Structural performance of glass fibre reinforced polymer laminated steel fibre reinforced concrete beams. Asian J Civ Eng 17(1):59-66

34. Spadea G, Bencardino F, Sorrenti F, Narayan swamy R (2015) Structural effectiveness of FRP materials in strengthening of RC beams. Eng Struct 99:631-641. https://doi.org/10.1016/j.engst ruct.2015.05.021

35. Hawileh A, Rasheed A, Abdul A, Timimi K (2014) Behavior of reinforced concrete beams strengthened with externally bonded hybrid fibre reinforced polymer systems. Mater Des 53:972-984. https://doi.org/10.1016/j.matdes.2013.07.087

Publisher's Note Springer Nature remains neutral with regard to jurisdictional claims in published maps and institutional affiliations. 